\title{
MATHEMATICIANS AND THE NEW SELECTIVE SERVICE REGULATIONS
}

On January 10, 1944, Selective Service Headquarters released amended Local Board Memoranda 115 and 115B, which become effective on February 1, and also an amended Activity and Occupational Bulletin No. 33-6, which becomes effective on February 15. These vitally concern all chairmen of departments of mathematics for they deal with the occupational classification of both teachers and undergraduate students. This communication contains a summary of the provisions of these directives.

Mathematicians are still included in the List of Critical Occupations. It is specifically stated that the titles included in Part II (Professional and Scientific Occupations) of the List of Critical Occupations "shall be considered as also including persons engaged in full-time teaching of these professions. A person may be considered as engaged in full-time teaching if he devotes not less than 15 hours per week in contact with students in actual classroom or laboratory instruction." The problem of securing the proper classification of a teacher of mathematics differs in accordance with the age group into which he falls.

\section{Deferment of Mathematicians in 18-21 Age Group}

All requests for new or additional occupational deferments for registrants in this age group who are teachers of mathematics must be made on Director of Selective Service Form 42-A Special. An original and two copies of this form must be presented by the employer to the State Director in whose state is located the registrant's principal place of employment.

Effective February 1, no registrant in this group, at the time he is classified, may be considered as a "necessary man" entitled to be placed in Class II-A or Class II-B unless:

(a) the State Director of Selective Service has endorsed his Form 42-A Special with a statement that, based on the information furnished therein, he recommends that the local board except the registrant from the general restrictions against occupational deferment of registrants aged 18 through 21 .

(b) he is classified as (1) belonging to the Personnel of the Merchant Marine or Army Transportation Corps or (2) as a student who qualifies under AOB 33-6. 
Registrants in this group who are classified II-A or II-B on February 1,1944 , will, in general, not have deferments terminated before the expiration date. (This, however, does not apply to students covered in the new AOB 33-6.)

The President and Secretary of the Society have addressed a memorandum to State Directors of Selective Service, calling attention to the vital need for these mathematicians to handle the mathematics in the Army Specialized Training Program and the Navy College Training Program.

\section{Deferment of Mathematicians in 22-37 Age Group}

In making requests for occupational deferment, one copy of Form 42-A must be filed with the local board, as heretofore. The local board may, without going further, classify the registrant in II-A or II-B, as requested.

If the registrant is not classified in II-A or II-B and if reference to the United States Employment Service was not made by the local board prior to classification in I-A, I-A-O or IV-E, it must be made immediately after such classification. Upon suitable certification from the USES, the local board must reopen the case. The cases of registrants who are qualified for professional and scientific occupations will be forwarded by the USES to the National Roster. In all cases in which reference to the USES is made, the local board is directed not to issue an order to report for induction until it has received a report from the USES or until the expiration of 30 days after referral, whichever occurs first. If, during the 30 -day period, the USES certifies to the local board that the registrant is qualified and that his removal would adversely affect the maintenance of his employer's required production, the local board must reopen the case and consider the new evidence as a basis for further deferment.

Even though a registrant is not employed in the area in which his local board is located, the registrant's local board must refer the case to the local USES office in the local board area and any further reference of the case to the USES office in which the registrant is employed will be undertaken and accomplished by the USES.

In view of these provisions, department chairmen are urged to register their needs for personnel with the USES office where the college or university is located and in the USES office where the registrant's local board is located. It is probable that the USES will be unable to supply any mathematicians but this is the best way to establish the fact that there is a shortage. If the USES does not have calls for mathematicians, physicists, engineers, chemists, et cetera, it will have no reason to believe that there is a shortage. 
The USES offices are required to refer cases involving scientific personnel to the National Roster. (Information has come to the Secretary to the effect that the USES offices are not now referring cases to the Roster.) If department chairmen believe that the advice given by the local USES office to the local board is inadequate or incorrect, the employer is advised to call the attention of the USES office to the instructions in Sections 5300-5309 of the USES Manual (which contain instructions involving the National Roster). If Roster advice is not sought, the chairman will do well to report all facts in the case directly to the Roster.

Department chairmen are urged to make the original requests for occupational deferment as strong as possible and to make all possible appeals. Despite the curtailment of certain college training programs, chairmen are advised to continue requests for deferment, for the shortage of qualified mathematicians is still critical.

\section{Department of Undergraduates}

In Activity and Occupation Bulletin 33-6 the position is taken that the Army and Navy Training Programs will provide adequately for the needs of the armed forces. Student deferment is for civilian needs in war production and in support of the war effort.

Students who will graduate on or before July 1, 1944, in a considerable number of fields (including engineering branches, bacteriology, chemistry, forestry, geophysics, mathematics, meteorology, optometry, pharmacy, and physics including astronomy) are eligible for occupational deferment on certification by the institution and the National Roster.

An undergraduate who is a full-time student of chemistry, engineering, geology, geophysics, or physics who will graduate after July 1, 1944, will be eligible for occupational deferment, if he is properly certified by his institution and the National Roster and will graduate within 24 months from the date of certification and provided the national quota of 10,000 is not exceeded. Mathematics was not included in the list mentioned above, in spite of the strong protests of our Washington representatives. For undergraduate students in the 1821 age group, requests for deferment are made in duplicate on DSS Form 42 Special; for students over 22 years of age, Form 42 is used.

A national quota of 10,000 has been established for students who should be occupationally deferred at any one time by reason of pursuing courses of study in chemistry, engineering, geology, geophysics, and physics. Students deferred to graduate on or before July 1, 1944, and students deferred for reasons other than pursuing a course of study will not be counted against this quota. 
Requests for information needed by the National Roster to set up institutional quotas, et cetera, have already gone out to college presidents. Information regarding the procedures to be followed by institutions and departments concerned will be issued by the National Roster to college presidents in the near future. The departments concerned should be on the lookout for such information.

Department chairmen are requested to inform the Secretary of cases in which mathematicians are improperly classified. In this manner the War Policy Committee, through its Washington representatives, will be better able to present the needs of the mathematicians.

M. H. STONE,

President

J. R. KLINE,

Secretary

January 17, 1944. 